\title{
Application of positive matrix factorization to identify potential sources of water quality deterioration of Huaihe River, China
}

\author{
Jiping Jiang ${ }^{1} \mathbb{0} \cdot$ Afed U. Khan ${ }^{2} \cdot$ Bin Shi $^{3} \cdot$ Sijie Tang ${ }^{1} \cdot$ Jehanzeb Khan ${ }^{4}$
}

Received: 12 January 2017 / Accepted: 15 March 2019 / Published online: 29 March 2019

(c) The Author(s) 2019

\begin{abstract}
Identification of nonpoint source (NPS) pollution is essential for effective water management. In this study we used a combined approach of hierarchal cluster analysis (HCA) and positive matrix factorization (PMF) to identify NPS pollution for Huaihe River basin in China. $\mathrm{NH}_{3}-\mathrm{N}, \mathrm{COD}, \mathrm{DO}$ and $\mathrm{pH}$ were regularly monitored weekly over 2 years (2011-2012) from 27 monitoring stations subjected to high anthropogenic and natural changes. As identified by multiple correspondence analyses, the monitoring stations \#3, \#9 and \#21 are located away from the rest of sites. HCA classified all the stations into 4 groups. PMF identified four factors on each group and each season. They were associated with the major causes of Huaihe River water quality deterioration resulted by discharges inputs from urban, agricultural and industrial land uses. Seasonal NPS pollution variation was found, and it is possibly linked with natural processes, for instance hydrological regime. This research work demonstrates the usefulness of PMF model for the identification of NPS pollution in surface waters. Furthermore, our study also shows that urban, agricultural and industrial land uses were the main factors impairing surface water quality, and limiting NPS pollution would be critical for enhancing surface water quality in the study area.
\end{abstract}

Keywords Cluster analysis $\cdot$ Nonpoint source pollution $\cdot$ Positive matrix factorization $\cdot$ Water quality $\cdot$ Huaihe River

\section{Introduction}

Water environment degradation is a big issue in watershed management, which poses severe threat to surface water security. Natural and anthropogenic activities deteriorate surface water quality (Sundaray et al. 2006), i.e., rock-water interactions ( $\mathrm{Li}$ et al. 2013), nutrient losses, municipal and industrial wastewater emissions, excessive sluice and dam

Jiping Jiang

jiangjp@sustech.edu.cn

1 State Environmental Protection Key Laboratory of Integrated Surface Water-Groundwater Pollution Control, School of Environmental Science and Engineering, Southern University of Science and Technology, Shenzhen 518055, China

2 Department of Civil Engineering, University of Engineering and Technology, Bannu Campus, Peshawar, Bannu 25000, Pakistan

3 State Key Laboratory of Urban and Regional Ecology, Research Center for Eco-Environmental Sciences, Chinese Academy of Sciences, Beijing 100085, China

4 Department of Horticulture, Zhejiang University, Hangzhou 310058, China constructions (Zhang et al. 2010). Huaihe River water quality is degraded due to rapid industrialization, urban sprawl and agriculture intensification (Di-hu 2005; Hu et al. 2009; Li and Pu 2003; Li et al. 2003; Xiao et al. 2011). In 2012, $31 \%$ water quality monitoring sites located at seven major rivers of China were reported having inferior (grade IV) water quality. Among the degraded monitoring sites 50\% stations located at Huaihe River were severely polluted. Water quality of Huaihe River is degrading in that last decades, and major areas across the province do not meet the national surface water quality standards. Therefore, identification of NPS pollution will excavate potential causes of water quality degradation caused by natural and anthropogenic interventions which will help in sustainable water resource management.

Rivers are the major source for carrying off point source pollution and NPS pollution. NPS pollution mainly occurs through surface runoff from various kinds of land uses (Whitehead et al. 2009). Overall, different types of land uses, which include urban, industrial, forest, agricultural and grass area, have shown relationships with NPS pollution. For example, agricultural land use has positive correlation with $\mathrm{NH}_{3}-\mathrm{N}$, while forest and grass areas have positive 
association with dissolved oxygen (DO) (Huang et al. 2013). Urban land use has positive relationship with chemical oxygen demand (COD) and pH (Huang et al. 2013; Pratt and Chang 2012). Industrial land use has been linked with COD (Zhao et al. 2015). Generally, urban and industrial land uses have negative impacts, while forest and grass land uses have positive impacts on surface water quality.

Multivariate statistical techniques which include factor analysis (FA), principal component analysis (PCA), cluster analysis (CA) and discriminant analysis (DA) are excessively used to analyze the complex multidimensional water quality dataset for the identification of NPS pollution in surface waters to better understand the ecological and water quality status of the studied systems (Alberto et al. 2001; Ali et al. 2016; Banerjee et al. 2016; Bilgin and Konanç 2016; Khound and Bhattacharyya 2017; Kuang et al. 2016; Singh et al. 2004; Wang et al. 2017; Yin et al. 2005). Multivariate statistical approaches have been applied to assess spatiotemporal patterns associated with anthropogenic and natural factors (Helena et al. 2000; Singh et al. 2004). PCA is widely used to identify spatiotemporal factors influencing stream health (Bengraïne and Marhaba 2003; Parinet et al. 2004).

Literature shows that PMF model is successfully applied for ambient particulate matter source appointment (Henry and Christensen 2010; HOPKE 2010). Besides the ambient air pollution, this technique is also used to investigate the contribution of various sources in wet pollutant deposition by utilizing TOC, $\mathrm{NH}_{4}-\mathrm{N}, \mathrm{NO}_{3}-\mathrm{N}, \mathrm{Mg}, \mathrm{K}$ and $\mathrm{Ca}$ as source tracers (Anttila et al. 1995). Recently, its application has been extended for pollutant source apportionment in aqueous environment using source markers such as $\mathrm{TP}, \mathrm{NH}_{3}$, heavy metals and $\mathrm{BOD}_{5}$ (biochemical oxygen demand) from combined sewer overflows ( $\mathrm{Li}$ et al. 2015; Soonthornnonda and Christensen 2008). Factor analysis (FA) and principal component analysis (PCA) are widely used for surface water quality source apportionment (Huang et al. 2011; Singh et al. 2004; Zhou et al. 2007). However, source apportionment for surface water quality based on water quality data matrix of monitoring stations using PMF is very rare which motivates the author for the current study.

$\mathrm{PMF}$ is an emerging technique with some of the advantages over the other multivariate techniques such as PCA, FA and UNMIX. These advantages include the inclusion of uncertainty calculation that allows individual treatment of the data matrix and the integration of nonnegativity constrains on the resulting factors in the computational process. PMF has been demonstrated to be superior to eigenvectorbased FA in many environmental applications. The estimation of uncertainties in PMF modeling allows better treatment of below detection and missing values (Hoinaski et al. 2013), since environmental data matrix usually contains data points below detection limit and missing values (Carrer and Leardi 2006). Henry and Christensen (2010) have introduced
PMF in the aqueous environment to down weight the uncertainties in the dataset to bring reasonable results (Henry and Christensen 2010).

Huaihe River, 7th largest river of China, poses serious threats to the national security and socioeconomic development of the country owing to frequent water pollution incidents. Spatiotemporal pattern of NPS pollution identification is an effective approach for water quality evaluation. The main aims of this research work were to identify and apportion spatiotemporal NPS pollution which originates from different land uses and to describe distribution patterns of the pollutants of Huaihe River. A combined approach was proposed in this work. Namely, the data were subjected to hierarchical clustering analysis (HCA) followed by modeling with PMF to identify potential NPS pollution. This research will provide technical foundation for water quality management based on identified NPS pollution in Huaihe River basin to bring sustainability in the region and provide scientific basis for the implementation of water pollution control plan in future.

\section{Materials and methods}

\section{Huaihe River basin and its pollution control project}

Huaihe River basin $\left(117^{\circ} 36^{\prime} \mathrm{E}-118^{\circ} 57^{\prime} \mathrm{E}, 29^{\circ} 21^{\prime} \mathrm{E}-30^{\circ} 13^{\prime} \mathrm{E}\right.$; Fig. 1) is overcrowded in terms of both water projects $\left(1 \mathrm{dam} / 50 \mathrm{~km}^{2}\right.$ ) and population (614 persons $/ \mathrm{km}^{2}$ ) and highly contaminated basin in China. It passes through five major provinces, i.e., Hubei, Henan, Anhui, Shandong and Jiangsu. It is a very important river owing to its big catchment area of $270,000 \mathrm{~km}^{2}$. The above-stated basin receives $894 \mathrm{~mm}$ annual precipitation, almost $70 \%$ of which is received during the rainy season from June to October. Significant spatial variation is observed in precipitation which ranges from $1400 \mathrm{~mm}$ in the southern mountain region to less than $700 \mathrm{~mm}$ in the northern region near the Yellow River. In total, $51 \%$ annual runoff is stored by dams and sluices (Liu et al. 2017). Both point and NPS pollution degrade surface water quality. More than $50 \%$ water quality monitoring stations are below Grade III of the country standards. Inferior surface water quality damage water environment and ecology (Zhang et al. 2010; Xia et al. 2018). In 1994, Huaihe River pollution control project was initiated whose aim was to control Huaihe River pollution till the end of the last century. Some improvement was brought by closing industries and enhancing sewage treatment facilities. In 2004, sudden paroxysmal chemical spill incidents dramatically impact the effects of pollution control (Wang et al. 2017). According to the regulations on the prevention and control of water pollution in the Huai River basin of Anhui Province, passed at November 2018, the local government is making efforts to 


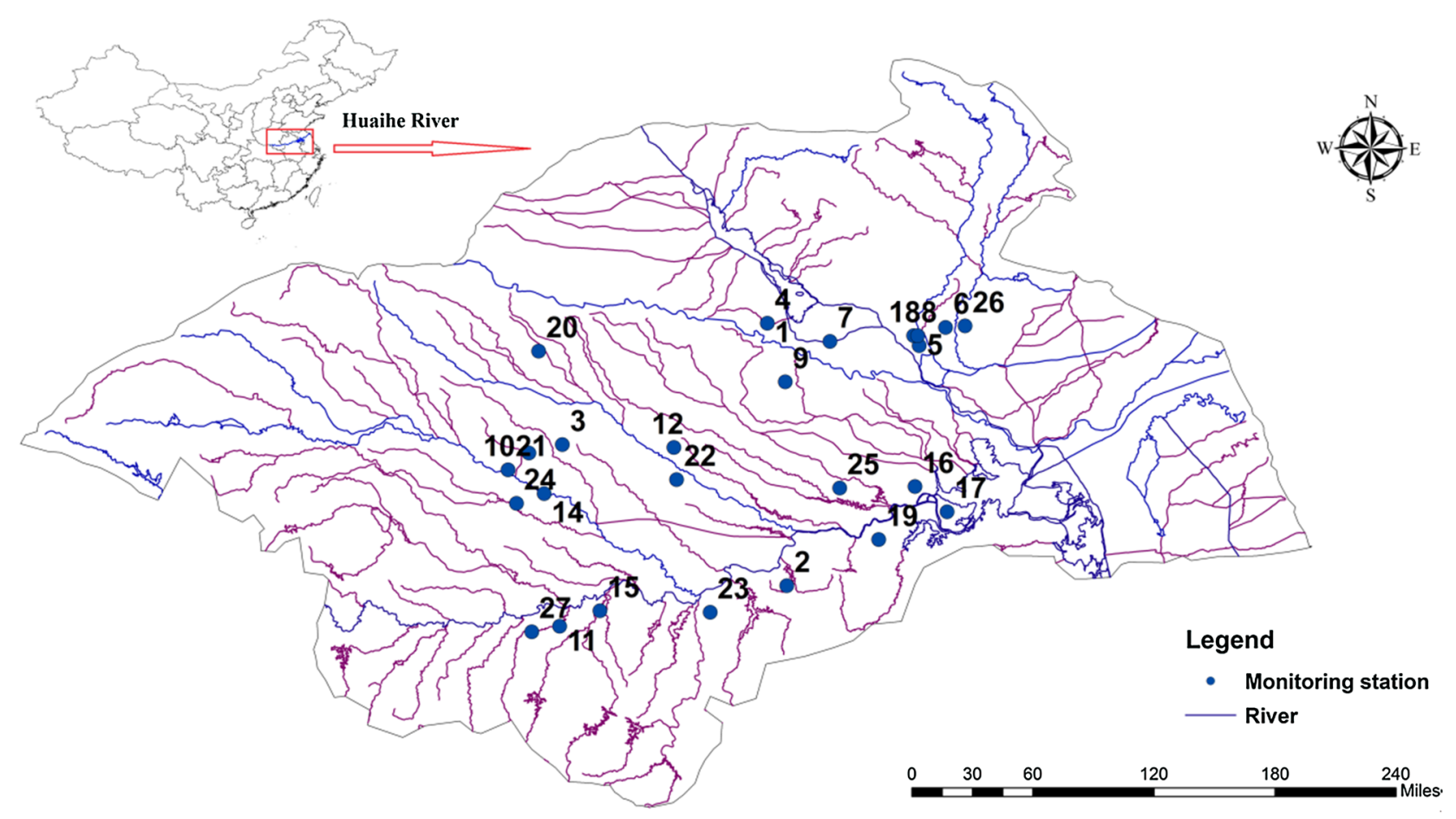

1.Aishanxi Bridge 2.Bengbu gate 3.Yanji in Gaozhou 4.Liji Bridge 5.Laogou Bridge 6.Qingquansi 7.Taierzhuang Bridge 8.Xiaohongquan 9.Yangzhuang 10.Xuzhuang 11.Jiangji hydrometric station 12.Huangkou 13.Fuqiao gate 14.Shenqiu gate 15.Bantai 16.Daqu in Sihong 17. Huaihe Bridge 18.Chongfang Bridge 19.Xiaoliuxiang 20.Wangjiaba 21.Zhangda Bridge 22. Huaibei Bridge 23. Shitoubo 24.Qidukou 25.Gonglu Bridge 26. Daxing Bridge 27. Huaibin Hydrometic station

Fig. 1 Spatial distributions of water quality monitoring stations of Huaihe River basin

achieve the goal that the proportion of good water quality monitoring section reached more than $57.5 \%$ in 2020.

\section{Data treatment and multivariate statistical methods}

Online monitoring stations were nationally installed by Chinese government since 2008. In this work, two-year (2011-2012) weekly monitoring data were collected from 27 water quality monitoring stations located along the main stretch of Huaihe River. The data included four water quality parameters, namely $\mathrm{COD}, \mathrm{DO}, \mathrm{pH}$ and $\mathrm{NH}_{3}-\mathrm{N}$. In the year 2011-2012, the water quality is not as good as 2018 and it makes the pollution apportionment more sensitive. Table 1 showed the basic statistic index of the water quality time series.

In this study a combined approach of HCA-PMF was conducted to apportion NPS pollution (Simeonov et al. 2003). Firstly, the data were standardized by z-scale transformation (normalized to zero mean and unit variance) to avoid misclassification owing to variables measured on different scales (Liu et al. 2003). Standardization put different water quality variables values on the same scale. This process allows comparing values between different types of water quality variables. Standardized values of water quality variables were obtained by subtracting mean from observed values and dividing by standard deviation. Next, HCA-PMF was used to classify water quality monitoring stations and to identify NPS pollution. Thereafter, multiple correspondence analysis (MCA) was used to visualize spatial distribution patterns of the water quality monitoring stations. Individual approaches were explained as below.

\section{Hierarchical cluster analysis (HCA)}

HCA is a statistical technique which groups up objects based on similar water quality characteristics (Chen et al. 2015; Li et al. 2009; Singh et al. 2004). HCA is based on sequential grouping which starts from the most similar characteristics pair and develops higher groups step by step. The process of forming and linking groups is repeated until a single group comprising all samples is acquired. The result can be displayed in the form of dendrogram which shows the graphical summary of the clustering process.

HCA used Ward's method with Euclidean distance as a measure of similarity. HCA clustered similar sampling

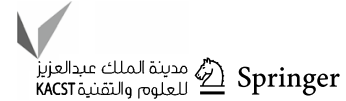


Table 1 Mean and standard deviation of water quality parameters at 27 monitoring stations of Huaihe River during 2011-2012

\begin{tabular}{|c|c|c|c|c|c|c|c|c|}
\hline \multirow[t]{2}{*}{ Site number and name } & \multicolumn{2}{|l|}{$\mathrm{pH}$} & \multicolumn{2}{|l|}{ DO } & \multicolumn{2}{|l|}{ COD } & \multicolumn{2}{|l|}{$\mathrm{NH}_{3}-\mathrm{N}$} \\
\hline & Mean & Std. dev. & Mean & Std. dev. & Mean & Std. dev. & Mean & Std. dev. \\
\hline 1. Aishanxi bridge & 8.0485 & 0.59116 & 9.8806 & 3.74713 & 5.7157 & 3.47870 & 0.4919 & 0.59018 \\
\hline 2. Bengbu gate & 7.8112 & 0.39694 & 7.7363 & 2.60232 & 3.4626 & 0.52664 & 0.4000 & 0.26037 \\
\hline 3. Yanji in Gaozhou & 8.2749 & 0.38361 & 3.5648 & 2.28371 & 15.5310 & 3.48217 & 6.4920 & 4.65212 \\
\hline 4. Liji bridge & 7.9434 & 0.54190 & 7.4342 & 1.59357 & 5.3119 & 0.39949 & 0.3499 & 0.22586 \\
\hline 5. Laogou bridge & 7.7366 & 0.30751 & 9.5541 & 2.68900 & 6.3893 & 1.47513 & 0.8460 & 0.64546 \\
\hline 6. Qingquansi & 7.9278 & 0.44928 & 10.2865 & 2.52366 & 6.0302 & 1.22559 & 0.4203 & 0.22227 \\
\hline 7. Taierzhuang bridge & 7.9255 & 0.46952 & 6.5761 & 1.03281 & 3.7724 & 0.72198 & 0.3886 & 0.12145 \\
\hline 8. Xiaohongquan & 8.1181 & 0.46811 & 8.9805 & 3.83277 & 6.3520 & 2.86580 & 0.3400 & 0.33466 \\
\hline 9. Yangzhuang & 8.0546 & 0.23500 & 5.5619 & 2.64725 & 18.5510 & 17.61235 & 4.8034 & 4.59909 \\
\hline 10. Xuzhuang & 8.0075 & 0.25896 & 6.9315 & 2.52185 & 9.7380 & 3.99813 & 0.5747 & 0.45402 \\
\hline 11. Jiangji hydrometric station & 7.7288 & 0.31356 & 8.9088 & 1.98738 & 2.4448 & 0.49497 & 0.2952 & 0.15072 \\
\hline 12. Huangkou & 7.8844 & 0.45430 & 10.1702 & 3.04597 & 7.1905 & 1.93478 & 0.2770 & 0.15917 \\
\hline 13. Fuqiao gate & 8.6592 & 0.35625 & 7.6375 & 1.20575 & 5.7838 & 1.33662 & 0.2234 & 0.20372 \\
\hline 14. Shenqiu gate & 8.0783 & 0.36140 & 6.7196 & 2.66782 & 4.8514 & 1.44709 & 1.1715 & 0.96165 \\
\hline 15. Bantai & 7.5646 & 0.53178 & 8.2464 & 2.03544 & 5.6179 & 1.20527 & 0.7170 & 0.31895 \\
\hline 16. Daqu in Sihong & 8.1620 & 0.38741 & 8.4891 & 2.69093 & 4.4837 & 2.31313 & 0.3169 & 0.39280 \\
\hline 17. Huaihe bridge & 7.9412 & 0.42463 & 8.6879 & 2.68553 & 4.2436 & 0.70502 & 0.5510 & 0.23220 \\
\hline 18. Chongfang bridge & 7.8653 & 0.29912 & 9.8705 & 2.23733 & 3.8333 & 0.74184 & 0.3082 & 0.22067 \\
\hline 19. Xiaoliuxiang & 8.1156 & 0.26817 & 8.3370 & 2.34624 & 3.0895 & 0.44309 & 0.3673 & 0.27739 \\
\hline 20. Wang jiaba & 7.6412 & 0.21730 & 7.8846 & 2.24604 & 4.6962 & 0.86011 & 0.6789 & 0.27773 \\
\hline 21. Zhangda bridge & 8.2546 & 0.32781 & 4.9500 & 3.11426 & 10.7448 & 3.75446 & 3.9147 & 3.18080 \\
\hline 22. Huaibei bridge & 8.2320 & 0.47032 & 9.2750 & 3.39046 & 6.3581 & 1.67394 & 0.5177 & 0.42707 \\
\hline 23. Shitoubo & 8.1142 & 0.34988 & 7.7419 & 2.56480 & 3.9095 & 0.72411 & 0.4736 & 0.25408 \\
\hline 24. Qidukou & 7.9678 & 0.30877 & 7.0515 & 3.05197 & 6.0352 & 1.95153 & 1.4018 & 1.08020 \\
\hline 25. Gonglu bridge & 8.3779 & 0.46972 & 10.5454 & 3.48189 & 6.1029 & 1.38227 & 0.1145 & 0.08705 \\
\hline 26. Daxing bridge & 8.0865 & 0.45837 & 9.8073 & 3.09689 & 4.5486 & 1.38641 & 0.5944 & 0.46004 \\
\hline 27. Huaibin hydrometric station & 7.7243 & 0.34225 & 8.5110 & 2.02062 & 3.2990 & 0.34738 & 0.3041 & 0.15865 \\
\hline
\end{tabular}

stations (spatial variability), based on four water quality parameters, located along the river stretch. HCA resulted in a dendrogram where linkage distance (rescaled) is represented on y-axis (Huang et al. 2014).

\section{Positive matrix factorization (PMF)}

PMF is widely used for source apportionment because it is one of the most important receptor models (Al-Dabbous and Kumar 2015; Hajigholizadeh 2016; Li et al. 2015; Mohammed et al. 2016). PMF is a multivariate receptor model that decomposes a matrix $X$ of $n$ by $m$ dimensions, in which $n$ is the number of samples and $\mathrm{m}$ is chemical species, into two matrices: factor contributions $(G)$ and factor profiles $(F)$, and the residual $(E)$ (see Eq. 1). Two input files were inserted into PMF model: a file containing concentrations of the four examined water quality parameters and a file containing uncertainty values that is calculated as per Eq. 2 . Optimum numbers of factors were obtained by performing several runs of the model and the subsequent selection of the best run/solution with the lowest values of $\mathrm{Q}$ (robust) where the later parameter shows the model fitting capability as mentioned earlier (Bzdusek et al. 2006). To minimize $\mathrm{Q}$, this parameter has been defined as per Eq. 3. The main task of factor analysis by PMF is to minimize the objective function $(Q)$ with respect to $\mathrm{G}$ and $\mathrm{F}$ under a constraint that all or at least some of the elements of the $\mathrm{G}$ and $\mathrm{F}$ were constrained to nonnegative values (Paatero 1997).

$X=G F+E$

The uncertainties were calculated using Eq. 2.

Uncertainty $=\frac{5}{6} * \mathrm{MDL}$

where MDL is method detection limit of each chemical species included as input in the modeling (Norris et al. 2014).

$Q=\sum_{i=1}^{n} \sum_{j=1}^{m}\left(e_{i j} / s_{i j}\right)^{2}$ 


\begin{tabular}{l} 
Bengbugate \\
Shitoubo \\
Wangjiaba \\
Jiangjihydrometricstation \\
Xiaoliuxiang \\
HuaibinHydrometicstation \\
HuaiheBridge \\
ChongfangBridge \\
DaxingBridge \\
DaquinSihong \\
Qingquansi \\
Bantai \\
LaogouBridge \\
GongluBridge \\
Huangkou \\
HuaibeiBridge \\
AishanxiBridge \\
Xiaohongquan \\
Qidukou \\
LijiBridge \\
Fuqiaogate \\
Yaierzhuangingangriugate \\
\hline
\end{tabular}

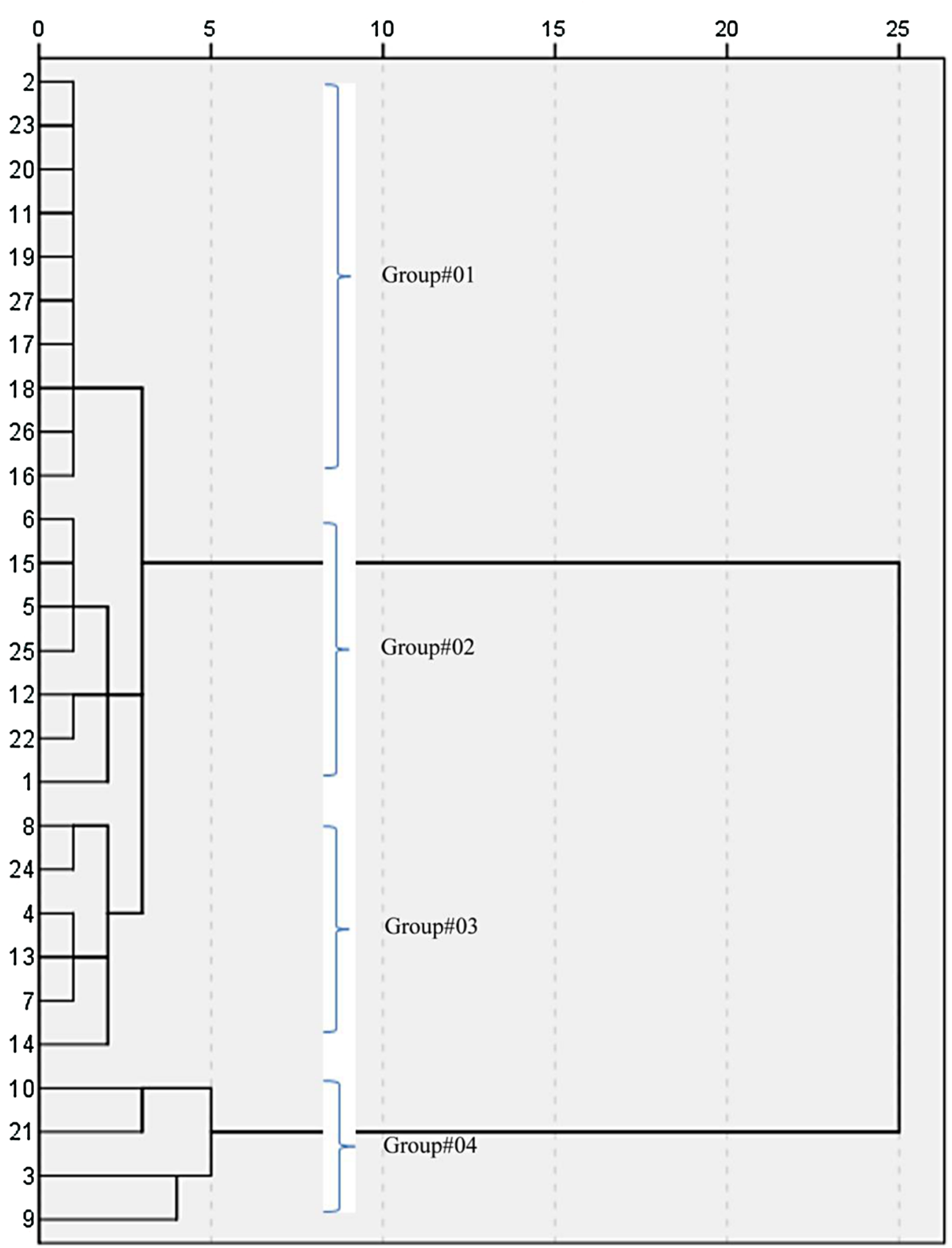

Fig. 2 Dendrogram of 27 water quality monitoring stations using Ward method based on water quality parameters of the Huaihe River basin

$Q=$ sum of squares of the difference $\left(e_{i j}\right)$ between the original data matrix $(X)$ and the PMF output $(G F)$, divided by the computed uncertainties $\left(s_{i j}\right)$.

The study was carried out using EPA PMF 5 which is based on Pateros's PMF model. Optimum numbers of factors were found by the value of $\mathrm{Q}$ which shows the model fitting capability. A global minimum was computed by changing the seed value from 1 to 20 for each model run (Bzdusek et al. 2006).

\section{Multiple correspondence analysis (MCA)}

Correspondence analysis is a statistical visualization technique illustrating association between the members of two sets of data. MCA is the advanced form of correspondence analysis, which analyzes multiway tables. MCA allows the establishment of relationships between two and more than two variables. The main purpose of MCA is to find categories and distinguish them by separating. The same category 


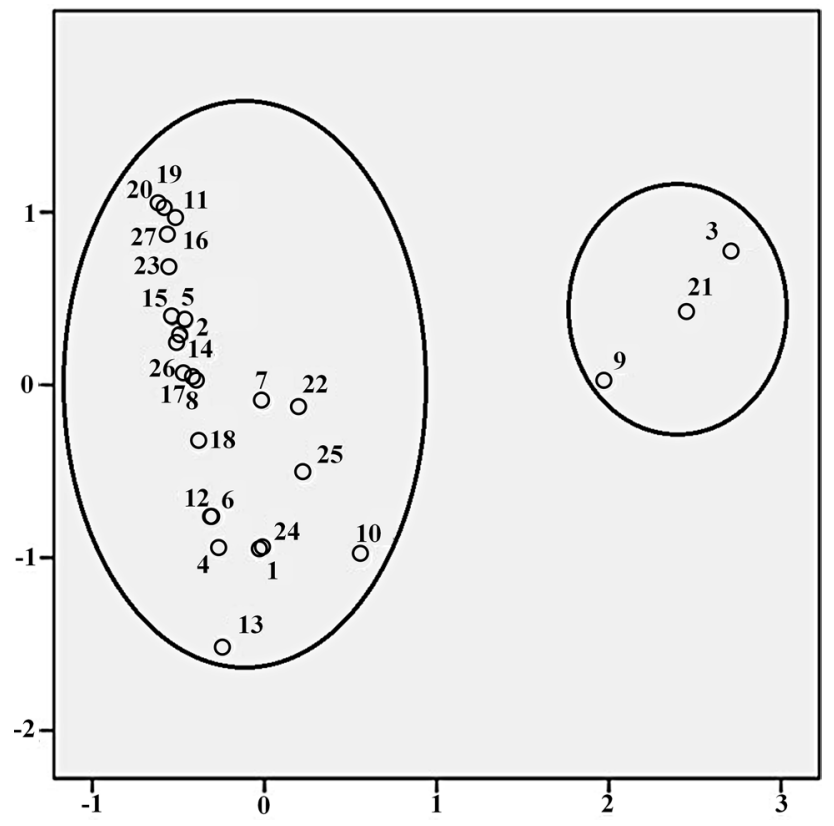

Fig. 3 MCA categorizes water quality monitoring stations at Huaihe River basin based on mean values of water quality parameters

variables are plotted close to one another, while different categories variables are plotted far apart (Ambarita et al. 2016; Pacheco 1998). Here, we performed MCA to categorize 27 water quality monitoring stations located along the river stretch. MCA categorized water monitoring sites to visualize its spatial distribution based on four water quality parameters (Fig. 3).

\section{Results}

Spatiotemporal variation of water quality data matrix was evaluated using different multivariate statistical techniques along with PMF modeling. Water sampling stations were broadly classified into four significant clusters as shown by dendrogram in Fig. 2. To assess spatial similarity among clusters, HCA was applied to 27 water quality monitoring sites. HCA classified the above-stated monitoring stations into four groups of similar water quality characteristics based on the four water quality parameters being analyzed in this study. The results are demonstrated by dendrogram as obvious from Fig. 2. HCA helps in declining the number of monitoring stations with minor loss of information (Simeonov et al. 2003).

MCA was carried out to find out spatial distribution patterns of water quality monitoring stations at Huaihe River basin. Some water quality monitoring stations (3, 9 and 21) are located away from the rest of sites. Apart from these three water quality monitoring stations, the remaining stations are close to each other as demonstrated in Fig. 3. This gives an idea that the majority features of the abovestated three water quality monitoring stations are different from the remaining stations owing to unique pollutant emission sources. Those stations which have similar characteristics lie close to each other as they are exposed to approximately the same NPS pollution (Ambarita et al. 2016; Zhao et al. 2015).

PMF analysis was carried out for the apportionment of NPS pollution originating from different land uses. It suggested certain number of NPS pollution factors based on the underlying principle mentioned earlier in the materials and methods' section. Each time the model was run using different initial seed value. The model was run 20 times. Four NPS pollution factors were identified per each group and per each season (winter, summer (wet), spring and autumn (wet)).

Four pollution sources are identified for winter season. All parameters are contributing in Factor 1(pH,35.5\%; DO, 61.6\%; COD, 21.5\%; and $\mathrm{NH}_{3}-\mathrm{N}, 5.8 \%$ ) and Factor 3(pH,43.2\%; DO,34.4\%; COD,29.9\%; and $\mathrm{NH}_{3}-\mathrm{N}, 12.4 \%$ ). Factor 1 and Factor 3 are identified as diffused land use with multiple NPS pollution. This may be due to closing of gates in dry season to store water for local supply which retains all kinds of pollutants produced from agricultural, industrial and urban land uses (World Bank, 1997). Factor 2(pH,3.3\%; COD, $8.8 \%$; and $\mathrm{NH}_{3}-\mathrm{N}, 75.5 \%$ ) is characterized by unique high loading of $\mathrm{NH}_{3}-\mathrm{N}$ and negligible loadings of the remaining three water quality parameters. Hence, this factor is identified as agricultural land use. Huaihe River basin is the main grain-producing area of China. This may be due to excessive application of fertilizers and pesticides used for crop production in the river valley (Zhong 2006). Factor 4 is dominated by $\mathrm{pH}$ and $\mathrm{COD}$ as can be seen from Fig. 4. Factor 4(pH,18\%; DO,4\%; COD,39.8\%; and $\left.\mathrm{NH}_{3}-\mathrm{N}, 6.3 \%\right)$ is then suggested to be related to urban land use (Huang et al. 2013; Pratt and Chang 2012; Xiao et al. 2016; Zhao et al. 2015).

Four pollution sources are identified for summer season. Factor $1\left(\mathrm{pH}, 4.6 \%\right.$; DO,0.4\%; COD,7.7\%; and $\mathrm{NH}_{3}-\mathrm{N}, 80.3 \%$ ) is exclusively ruled by $\mathrm{NH}_{3}-\mathrm{N}$ as evident from the source profile shown in Fig. 4. Hence, this factor is most likely to be linked to agricultural land use. The profiles of agricultural land use in summer and winter are very similar. Rains in summer sweep fertilizers and pesticides from fields to the river. Factor $2\left(\mathrm{pH}, 1.6 \%\right.$; $\mathrm{COD}, 31.6 \%$; and $\left.\mathrm{NH}_{3}-\mathrm{N}, 1.5 \%\right)$ is dominated by COD and negligible loading of the rest water quality parameters and therefore classified as industrial land use. High loading of COD may be due to routine industrial activities accompanied by seasonal agricultural product processing enterprises at village and township level. It has aggravated the situation owing to outdated technology and lack of pollution treatment facilities (Zhong 2006). 

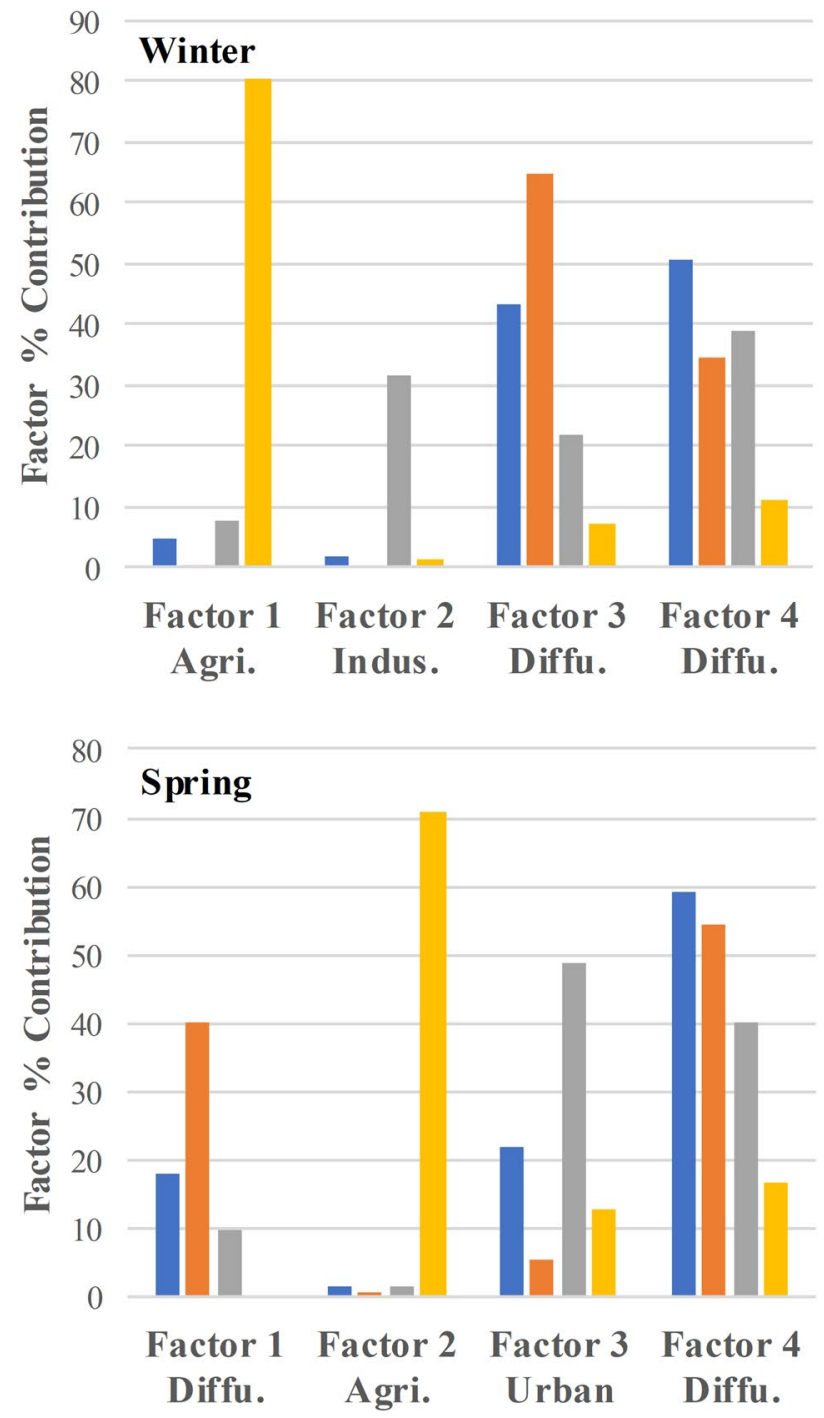

Fig. 4 Temporal factor loadings obtained from PMF analysis of water quality parameters of Huaihe River basin. Factors along with its corresponding NPS are given. (For winter season: Factor 1 and Factor $3=$ diffused land use, Factor $2=$ agricultural land use and Factor $4=$ urban land use. For summer season: Factor $1=$ agricultural land

All parameters are contributing in Factor $3(\mathrm{pH}, 43.2 \%$; DO, 64.9\%; COD, $21.7 \%$; and $\mathrm{NH}_{3}-\mathrm{N}, 7 \%$ ) and Factor 4(pH,50.6\%; DO,34.7\%; COD,38.9\%; and $\mathrm{NH}_{3}-\mathrm{N}, 11.2 \%$ ). Factor 3 and Factor 4 are identified as diffused land use with multiple NPS pollution. It may be attributed to high water consumption for bathing due to rise in temperature and heavy rains in those particular areas. Storm water sweeps all kinds of contaminants from different land uses to the river (Huang et al. 2013; Pratt and Chang 2012; Xiao et al. 2016; Zhao et al. 2015).

Four pollutant sources are identified for spring season. All parameters are contributing in Factor $1(\mathrm{pH}, 17.8 \%$; DO,39.9\%; and COD,9.6\%) and Factor 4(pH,59.2\%;
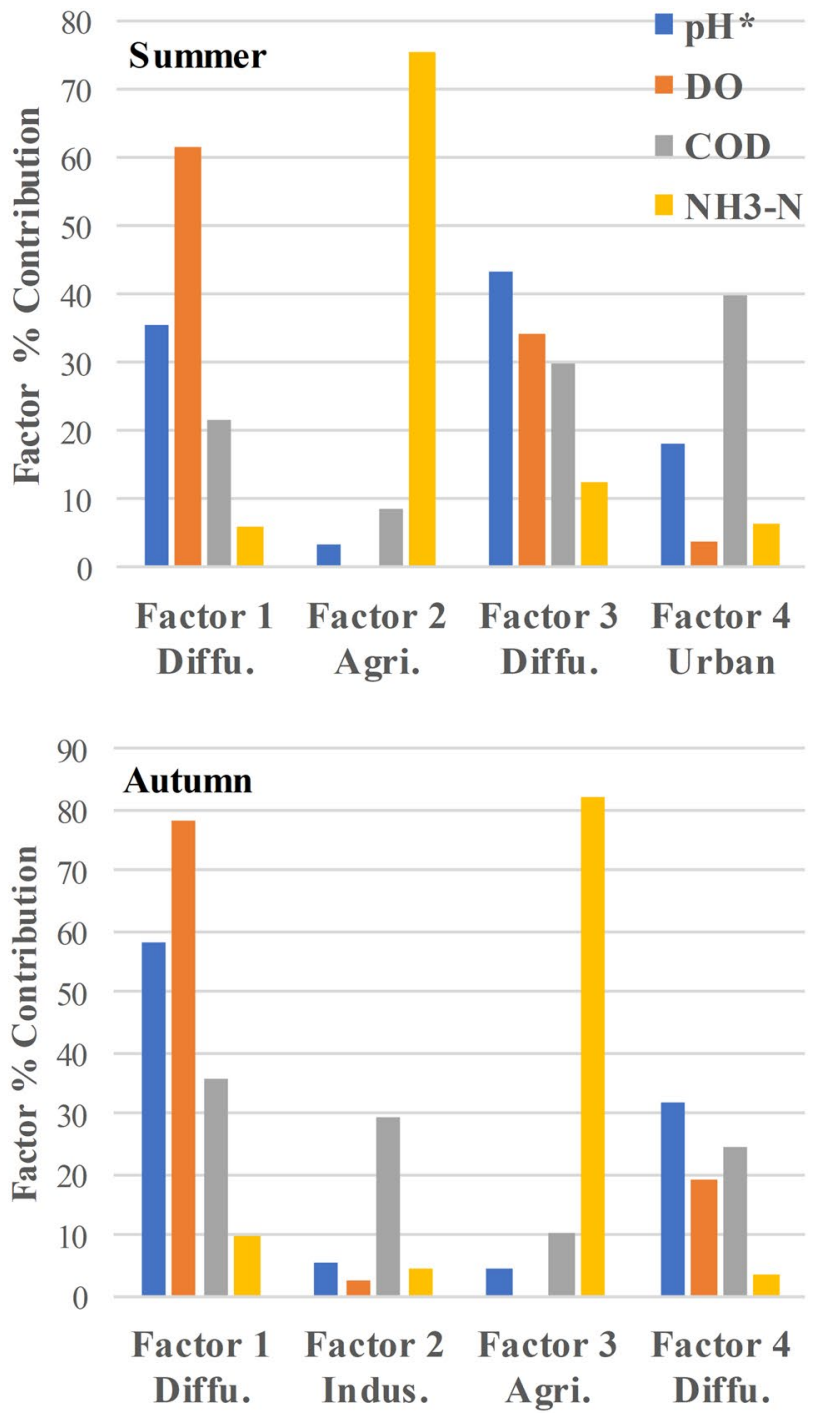

use, Factor $2=$ industrial land use, Factor 3 and Factor $4=$ diffused land use. For spring season: Factor 1 and Factor $4=$ diffused land use, Factor $2=$ agricultural land use and Factor $3=$ urban land use. For autumn season: Factor 1 and Factor $4=$ diffused land use, Factor $2=$ industrial land use and Factor $3=$ agricultural land use.)

DO,54.5\%; COD,39.9\%; and $\mathrm{NH}_{3}-\mathrm{N}, 16.6 \%$ ). Factor 1 and Factor 4 are identified as diffused land use with multiple NPS pollution owing to high anthropogenic activities due to favorable working temperature. Moreover, water storage for local usage in dry season has aggravated the situation by retaining all kinds of pollutants including agricultural, municipal and industrial (World Bank 1997). Factor $2\left(\mathrm{pH}, 1.3 \%\right.$; $\mathrm{DO}, 0.1 \%$; $\mathrm{COD}, 1.6 \%$; and $\left.\mathrm{NH}_{3}-\mathrm{N}, 70.7 \%\right)$ is classified as agricultural land use based on the unique elevated levels of $\mathrm{NH}_{3}-\mathrm{N}$ and negligible loadings of the rest of the water quality parameters. It shows moderately low agricultural activities during spring season as compared to winter and summer. This may be due to application of 
insecticides and fertilizers used for crops growth (Zhong 2006). Factor 3(pH,21.7\%; DO, $5.5 \%$; COD, $48.9 \%$; and $\left.\mathrm{NH}_{3}-\mathrm{N}, 12.6 \%\right)$ is dominated by $\mathrm{pH}$ and COD as evident from the profile illustrated in Fig. 4. Factor 3 is then identified as urban land use (Huang et al. 2013; Pratt and Chang 2012; Xiao et al. 2016; Zhao et al. 2015).

Four pollution sources are identified for autumn season. All parameters are contributing in Factor 1 and Factor 4 as apparent from the profile as shown in Fig. 4. Factor $1\left(\mathrm{pH}, 58 \%\right.$; DO, $78.3 \%$; $\mathrm{COD}, 35.8 \%$; and $\left.\mathrm{NH}_{3}-\mathrm{N}, 10 \%\right)$ and Factor $4(\mathrm{pH}, 31.8 \%$; DO, $19 \%$; COD, $24.7 \%$; and $\left.\mathrm{NH}_{3}-\mathrm{N}, 3.4 \%\right)$ are identified as diffused land use with multiple NPS pollution owing to rains. Storm water sweeps all kinds of contaminants from different land uses to the river. Factor 2(pH,5.7\%; DO, 2.7\%; COD, 29.2\%; and $\mathrm{NH}_{3}-\mathrm{N}, 4.3 \%$ ) is characterized by high concentrations of COD, and negligible loading of the remaining three water quality parameters is possibly an industrial land use. Factor $3(\mathrm{pH}, 4.5 \%$; $\mathrm{COD}, 10.3 \%$; and $\left.\mathrm{NH}_{3}-\mathrm{N}, 82.3 \%\right)$ is identified as agricultural land use with high loading of $\mathrm{NH}_{3}-\mathrm{N}$ and negligible loading of the rest water quality parameters. It shows agricultural activities accompanied by leaf fall during autumn season (Huang et al. 2013; Pratt and Chang 2012; Xiao et al. 2016; Zhao et al. 2015).

Spatial PMF analysis was carried out using the same data matrix of 4 water quality parameters clustered in four classes using HCA. Four NPS pollution has been identified per group. It is obvious from the profile of group\#01 that Factor 1(pH,20.5\%; DO,35\%; COD,28.7\%; and $\left.\mathrm{NH}_{3}-\mathrm{N}, 8.9 \%\right)$ and Factor $4(\mathrm{pH}, 38.1 \%$; DO, $45.7 \%$; $\mathrm{COD}, 16.2 \%$; and $\left.\mathrm{NH}_{3}-\mathrm{N}, 9.1 \%\right)$ are identified as diffused land use as all the parameters are contributing. It is composed of various kinds of land uses including lakes (Taodian and Kao Tang), forest land use (Laoxin River), agriculture land use, towns and villages. Factor $2(\mathrm{pH}, 6.9 \%$; DO,7\%; COD,7\%; and $\mathrm{NH}_{3}-\mathrm{N}, 76.1 \%$ ) is identified as agricultural land use as obvious from the high effluent of $\mathrm{NH}_{3}-\mathrm{N}$ produced due to fertilizer application. Agricultural activities are high in Hung Tse Lake area and Wang jiaba dam area due to abundant water for irrigation purposes. Factor $3(\mathrm{pH}, 34.4 \%$; DO, $12.3 \%$; COD, $48.2 \%$; and $\left.\mathrm{NH}_{3}-\mathrm{N}, 5.9 \%\right)$ is identified as urban land use with high chemical flux as obvious from high contribution of $\mathrm{pH}$ along with COD as obvious from Fig. 5. Pizhou, Fengyang, Shangqiu and Xinyi are thickly populated cities having multiple NPS pollution (Huang et al. 2013; Pratt and Chang 2012; Xiao et al. 2016; Zhao et al. 2015).

For group\#2, four NPS pollution is identified. It is obvious from the profile of group\#02 that Factor $1(\mathrm{pH}, 10.3 \%$; DO, $2.1 \%$; $\mathrm{COD}, 33.8 \%$; and $\mathrm{NH}_{3}-\mathrm{N}, 4.6 \%$ ) is most likely an urban land use. Dagoucun is thickly populated urban area having multiple NPS pollution. Factor $2(\mathrm{pH}, 10.7 \%$; DO,6.3\%; $\mathrm{COD}, 7.9 \%$; and $\left.\mathrm{NH}_{3}-\mathrm{N}, 76.4 \%\right)$ is identified as agricultural land use due to high effluent of $\mathrm{NH}_{3}-\mathrm{N}$ produced from widespread growing area due to application of fertilizers, with this claim supported by evidence that agricultural activities are high in Luoma lake area and Heilongtan reservoir area due to easy availability of crops water. Corn and peanut are the most popular crops of this area. Factor $3\left(\mathrm{pH}, 42 \%\right.$; DO, $67.5 \%$; $\mathrm{COD}, 30.7 \%$; and $\left.\mathrm{NH}_{3}-\mathrm{N}, 6.7 \%\right)$ and Factor 4(pH,37\%; DO,24.1\%; COD, $27.6 \%$; and $\mathrm{NH}_{3}-\mathrm{N}, 12.3 \%$ ) are identified as diffused land use. It is composed of various kinds of land uses including mountainous area (Yunlong), forest (Yunlong), water reservoir (Huang chao guan), corn fields and villages (Huang et al. 2013; Pratt and Chang 2012; Xiao et al. 2016; Zhao et al. 2015).

Four possible pollution sources are recognized for group\#03. Factor $1(\mathrm{pH}, 56.9 \%$; DO,79.2\%; COD,41.5\%; and $\mathrm{NH} 3-\mathrm{N}, 10.1 \%)$ and Factor $3(\mathrm{pH}, 9.1 \%$; DO, $10 \%$; COD, $22.5 \%$; and NH3-N,4.3\%) were identified as diffused land use with multiple emission sources. It is comprised of various kinds of land uses including agriculture land use, towns (Tashan, Chen Lou, etc.) and grass land use. Factor $2(\mathrm{pH}, 3.6 \%$; DO, $4.2 \%$; COD, $7.9 \%$; and $\mathrm{NH} 3-\mathrm{N}, 73.7 \%$ ) is identified as agricultural land use due to high effluent of $\mathrm{NH}_{3}-\mathrm{N}$. Along with grain crops, rape flowers (Linquan and Fujing area) are grown in this area. Factor $4(\mathrm{pH}, 30.4 \%$; DO, $6.5 \%$; COD, 28.1\%; and NH3-N,11.8\%) is suggested to be an urban land use as obvious from high contribution of $\mathrm{pH}$ along with COD. Nieloucun, Pengxinzhuang and Chenglizhuang are thickly populated urban areas producing various kinds of pollutants (Huang et al. 2013; Pratt and Chang 2012; Xiao et al. 2016; Zhao et al. 2015).

Four sources of pollution are suggested for group\#04. Factor $1(\mathrm{pH}, 16.1 \%$; DO,4.2\%; COD, $17 \%$; and $\mathrm{NH} 3-\mathrm{N}, 82.5 \%)$ with highest loading of $\mathrm{NH}_{3}-\mathrm{N}$ is probably an agricultural land use. This claim is supported by a fact that this area is popular for corn crops and soya bean growth. Agricultural activities are higher in Hua Jia Lake area owing to excessive amount of water for irrigation purpose. Factor $2(\mathrm{pH}, 38.5 \%$; DO, $13.3 \%$; COD, 31.5\%; and NH3-N,9.3\%) is identified as urban land use. Huaibei City is a thickly populated area with multiple NPS pollution. Factor 3 (pH, $2.7 \%$; DO, $1.8 \%$; $\mathrm{COD}, 39.9 \%$; and $\mathrm{NH} 3-\mathrm{N}, 1 \%$ ) is identified as industrial land use. Industrial estate is located in this area. Large numbers of industries are located in it which includes steel factories and its wire houses, chemical factories, electricity factory and mechanical factories, etc. Coal mine (Yonggu Mine) has also aggravated the situation. Factor $4(\mathrm{pH}, 42.7 \%$; DO, $80.7 \%$; COD, 11.6\%; and NH3-N,7.2\%) is identified as diffused land use. It is composed of various kinds of land uses including corn fields, aspen forests, pigeon forms and towns (Xincun, Shenqiu, etc.) (Huang et al. 2013; Pratt and Chang 2012; Xiao et al. 2016; Zhao et al. 2015).

It is safety to note from the above discussion that urban, industrial and agricultural land uses are the main contributor 

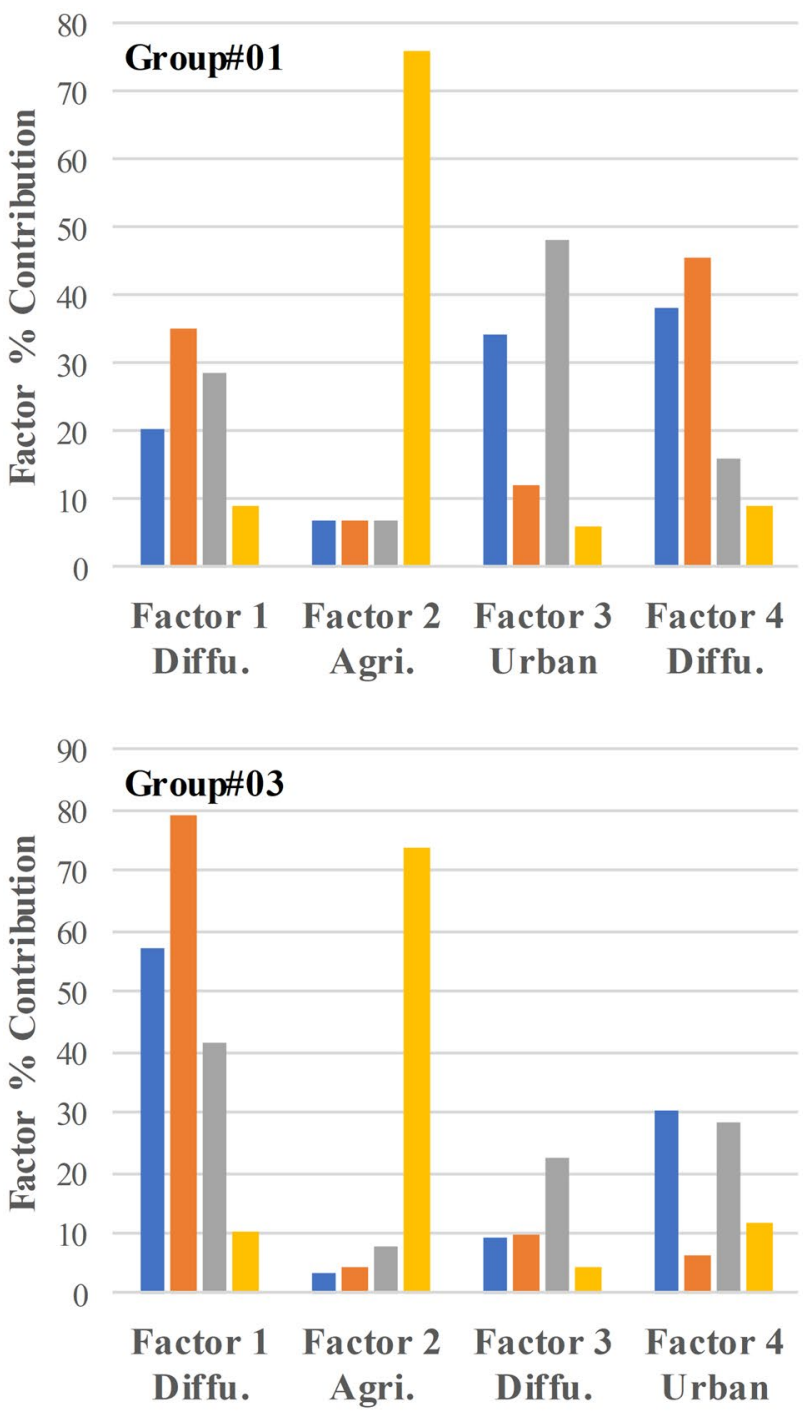

Fig. 5 Spatial factor loadings obtained from PMF analysis of water quality parameters of Huaihe River basin. (For group\#01: Factor 1 and Factor $4=$ diffused land use, Factor $2=$ agricultural land use and Factor $3=$ urban land use. For group\#02: Factor $1=$ urban land use, Factor 2 = agricultural land use, Factor 3 and Factor $4=$ dif-

for Huaihe river water quality impairment (Xiao et al. 2016). Anthropogenic activities play a vital role in river water quality impairment at urban communal level (Yin et al. 2005).

Box and whisker plot is a convenient graphical tool that helps to assess different patterns related to spatiotemporal variations in water quality as shown in Figs. 6 and 7. An uphill trend was observed in the concentration of DO owing to decreasing temperature in autumn, spring and winter as compared to summer. $\mathrm{pH}, \mathrm{COD}$ and $\mathrm{NH}_{3}-\mathrm{N}$ show increase in winter and spring over autumn and summer owing to dilution caused by excessive rains during summer and autumn seasons (Singh et al. 2004). pH shows minor uphill spatial gradient from group\#01 to group\#04
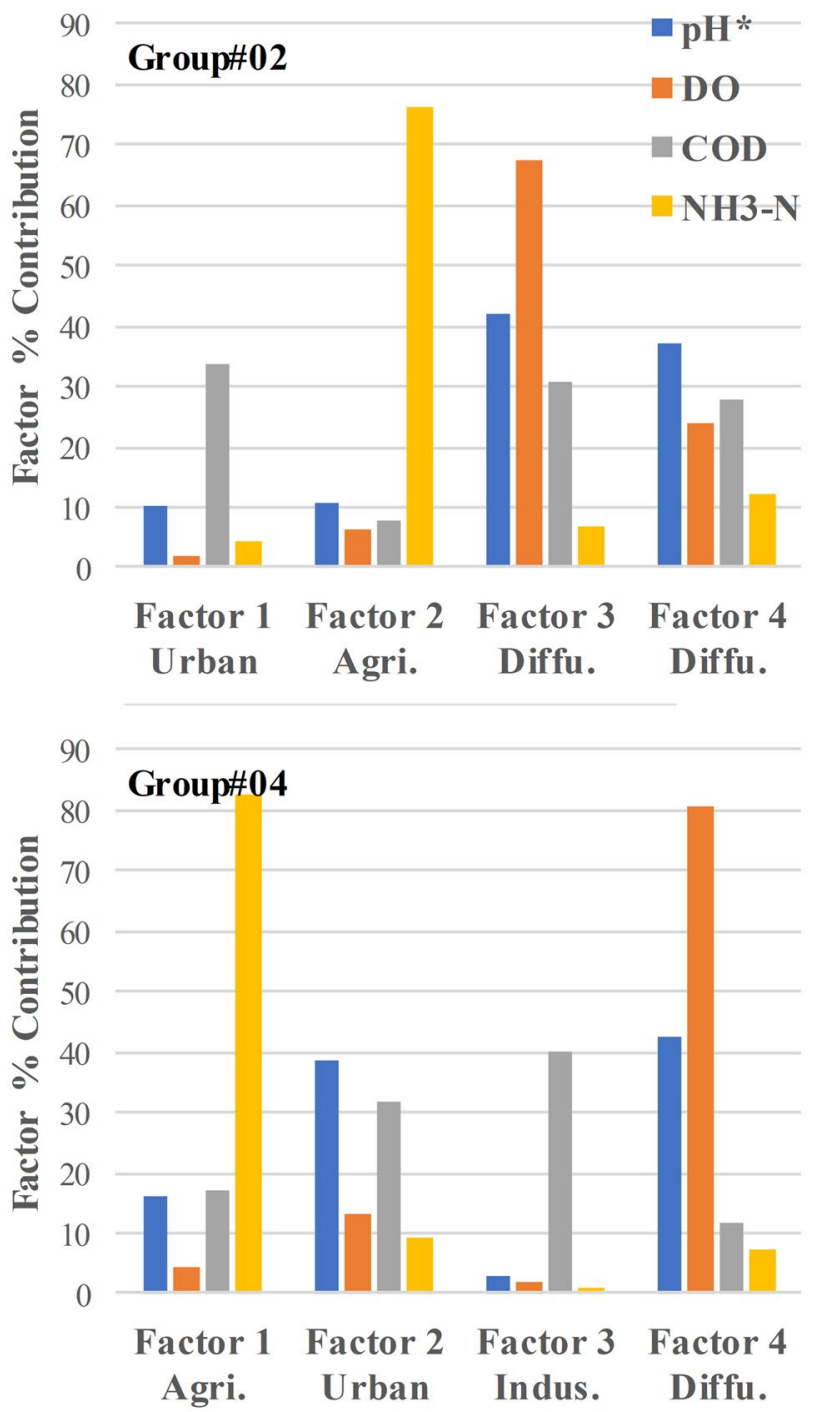

fused land use. For group\#03: Factor 1 and Factor 3 = diffused land use, Factor 2 = agricultural land use and Factor $4=$ urban land use. For group\#04: Factor $1=$ agricultural land use, Factor $2=$ urban land use, actor $3=$ industrial land use and Factor $4=$ diffused land use.)

as compared to other three water quality parameters as demonstrated in Fig. 7, owing to pollution load entering at some regions from several urban sources (Singh et al. 2004). Similarly, spatial pattern was observed in the concentration of DO as group\#02 shows uphill trend, while group\#03 and group\#04 show downhill trend as compared to group\#01 which shows its contamination level as shown in Fig. 7. Heavy loads of pollutants make entry from urban, industrial and agricultural land use in all those regions contained in group\#03 and group\#04. These regions show downhill trend in DO owing to oxygen consumption in organic matter decay. Similarly, spatial toxic uphill gradient was observed in both $\mathrm{COD}$ and $\mathrm{NH}_{3}-\mathrm{N}$

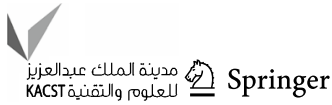



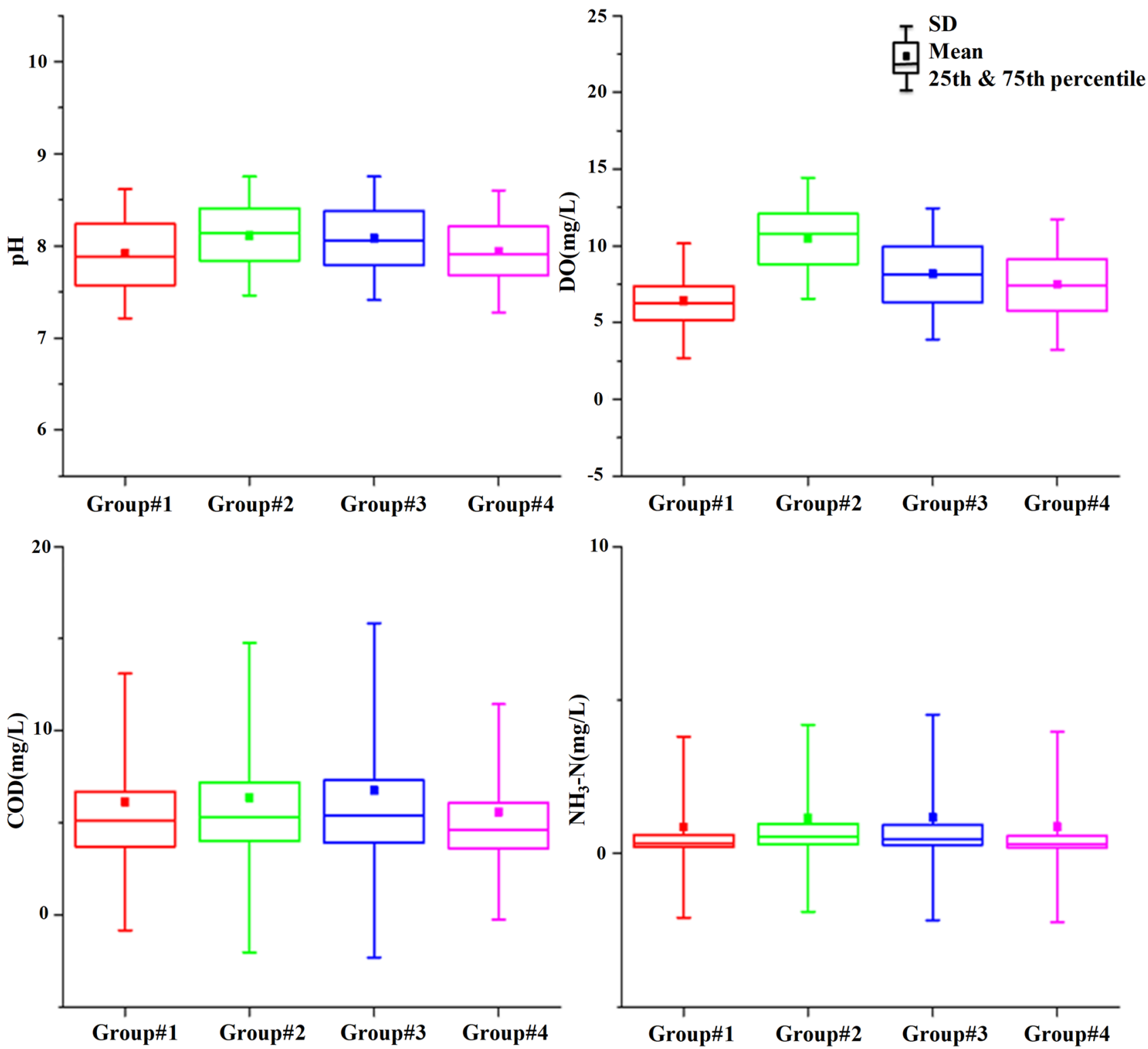

Fig. 6 Temporal variations of water quality parameters for Huaihe River basin

from group\#01 to group\#04 as shown in Fig. 7. It shows that these regions are vulnerable to intense toxicity from multiple NPS pollution originating from urban, industrial and agricultural land uses.

\section{Discussions}

\section{Contribution of land use to spatial water quality}

Literature shows that land uses are associated with point and NPS pollution (industrial and domestic sewage, livestock wastewater, irrigation tail water discharges, storm runoff) which degrade surface water quality (Huang et al. 2016). NPS pollution is prominent in rainy season, while point source pollution is dominant in dry season. Urban land continuously deteriorates river water quality throughout the year with strongest impacts in dry season (summer and autumn) due to lower dilution (Bu et al. 2014; Yu et al. 2016). This could be exemplified by high loading of COD across different seasons.

High loading of nitrogen parameters in surface water is attributed to overfertilization and erosion caused by surface runoff and irrigation tail water discharges (King et al. 2005; Tong and Chen 2002; Unwin et al. 2010). The elevated concentration of NH3-N in surface waters may be a 

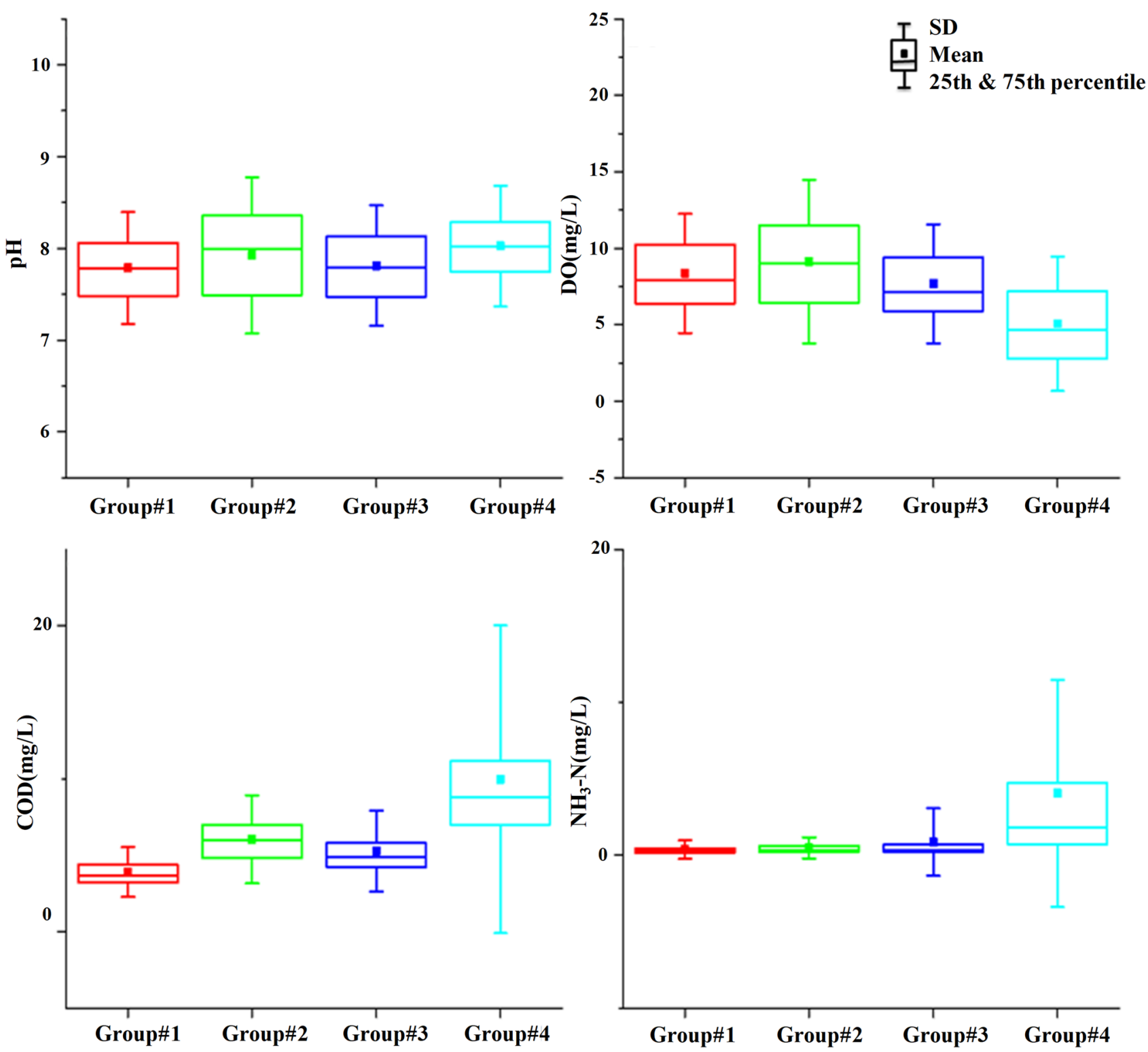

Fig. 7 Groupwise spatial variations of water quality for Huaihe River basin

consequence of irrigation tail water discharges due to favorable environmental condition in the region (Afed et al. 2017). Agricultural land continuously impairs surface water quality throughout the year with strongest impacts in dry season (summer and autumn) due to lower dilution (Liu et al. 2017). Industrial land use has positive association with COD. Water quality of industrial area is highly contaminated as compared to urban and suburban area (Zhao et al. 2015). Lacks of treatment facilities in industrial and urban area badly deteriorate surface water quality (Ding et al. 2015; Ho and Hui 2001; Sun et al. 2013).

\section{Contribution of land use to seasonal contamination risk}

Seasonal variation of surface water quality is associated with land use composition. The results of the current study suggested that water quality exhibits seasonality for a distinct land use composition for a particular site. Rainy season alters surface water quality due to instream flushing effect and dilution (Park et al. 2011) resulting in seasonal variations of point and NPS pollution (Ye et al. 2014). $\mathrm{NH}_{3}-\mathrm{N}$ and COD loading is higher in rainless season due to lower dilution effect. $\mathrm{NH}_{3}-\mathrm{N}$ concentration is higher in spring which may be due to 
high agricultural activities in the region (Liu et al. 2017). The study area is characterized by double cropping system, i.e., wheat and maize. Fertilizer application is common in March and April for winter wheat. Irrigation tailwater discharges due to conventional irrigation system in the study area deteriorate surface water quality via nutrient loss with soil erosion (Yu et al. 2016). Furthermore, seasonal first flush of rainfall is the second potential cause of water quality degradation (Liu et al. 2016). Late spring rainfall, after long dry season, drains fertilizers and pesticides to nearby watercourses which degrade surface water quality (Liu et al. 2017).

\section{Local management implication for Huaihe River}

NPS pollution strongly depends on land use which varies from one monitoring site to another monitoring site. Here, NPS pollutants are identified via multiple water quality variables. Therefore, it is necessary to implement comprehensive best management practices (BMPs) at various land use level to address multiple concerns of water quality deterioration. Seasonal variation of NPS pollution explains seasonal behavior of pollutants emission. NH3-N and COD concentration is higher in dry season in agricultural region and urbanized area. Agricultural and urban areas pose high risk of contamination during spring. The seasonal variability of NPS pollution can be beneficial in controlling seasonal contamination risk via BMPs (Liu et al. 2017). It is utmost important to control urban runoff in order to fulfill the country discharge standards, while sluices regulation, precision farming, terraced fields and buffer zone will be helpful in water quality improvement (Xia et al. 2018).

\section{Limitations}

Up to certain extent, the authors have faced problems in the apportionment of NPS pollution based on land use due to the following facts. First, the authors faced difficulty in the identification of NPS pollution owing to the availability of limited number of water quality parameters. Secondly, the authors faced problems due to unavailability of field benchmark NPS pollution emission profiles of different sources at different land use levels. Field NPS pollution emission profile of different sources works as benchmark for PMF results. Validation of PMF results can be done via field benchmark NPS pollution emission profiles.

\section{Conclusions}

The underlying information was extracted from the complex multidimensional water quality data matrix via multivariate statistical techniques and PMF analysis for Huaihe River basin. HCA clustered twenty-seven water quality monitoring stations into four groups of similar water quality characteristics based on four water quality parameters. MCA has identified that some water quality monitoring stations (3, 9 and 21) are located away from the rest which suggests that they have different water quality characteristics due to unique pollutant emission sources. Box and whisker plots have suggested that temporal trends are possibly influenced by temperature and rainfall, while spatial trends are linked with NPS pollution from different land uses, i.e., agricultural, urban and industrial land uses. PMF identified 4 factors per each group and each season based on land use which gives clear picture of NPS pollution originating from different land uses. Each factor identified by PMF analysis shows the severity of anthropogenic activities at different land use level. Besides, NPS pollution varies with season which shows its possible linkages with natural processes, for instance hydrological regime. The seasonal contamination patterns will be beneficial in controlling seasonal pollution risk. Generally, Huaihe River water quality was mainly impaired by land use variation, flows regulated by sluices and dams, etc. In high regulated rivers scientific regulation of dams and sluices may be helpful in alleviating water quality pollution problems. The proposed pollution apportionment approach supports the management and planning of the ongoing Huaihe River water pollution control project.

Acknowledgments This work was funded by the National Natural Science Foundation of China (Grant No.51509061) and the Fundamental Research Funds for the Central Universities (Grant No. HIT. NSRIF.2017060), and additional support was provided by the Southern University of Science and Technology (Grant No. G01296001). Particular thanks to anonymous reviewers for constructive suggestions.

Open Access This article is distributed under the terms of the Creative Commons Attribution 4.0 International License (http://creativeco mmons.org/licenses/by/4.0/), which permits unrestricted use, distribution, and reproduction in any medium, provided you give appropriate credit to the original author(s) and the source, provide a link to the Creative Commons license, and indicate if changes were made.

\section{References}

Afed UK, Jiping J, Peng W, Yi Z (2017) Influence of watershed topographic and socio-economic attributes on the climate sensitivity of global river water quality. Environ Res Lett 12:104012

Alberto WD, del Pilar DM, Valeria AM, Fabiana PS, Cecilia HA, de los Ángeles BM (2001) Pattern recognition techniques for the evaluation of spatial and temporal variations in water quality. A case study: suquía River Basin (Córdoba-Argentina). Water Res 35:2881-2894

Al-Dabbous AN, Kumar P (2015) Source apportionment of airborne nanoparticles in a middle eastern city using positive matrix factorization. Environ Sci Process Impacts 17:802-812

Ali MM, Ali ML, Islam MS, Rahman MZ (2016) Preliminary assessment of heavy metals in water and sediment of Karnaphuli river Bangladesh. Environ Nanotechnol Monit Manag 5:27-35

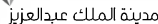

KACST 
Ambarita MND, Lock K, Boets P, Everaert G, Nguyen TH, Forio MA, Musonge PL, Suhareva N, Bennetsen E, Landuyt D, DominguezGranda L (2016) Ecological water quality analysis of the Guayas river basin (ecuador) based on macroinvertebrates indices. Limnol Ecol Manag Inland Waters 57:27-59

Anttila P, Paatero P, Tapper U, Jarvinen O (1995) Source identification of bulk wet deposition in finland by positive matrix factorization. Atmos Environ 29:1705-1718. https://doi.org/10.1016/13522310(94)00367-t

Banerjee S, Kumar A, Maiti SK, Chowdhury A (2016) Seasonal variation in heavy metal contaminations in water and sediments of Jamshedpur stretch of Subarnarekha river. India Environ Earth Sci 75:265

Bengraïne K, Marhaba TF (2003) Using principal component analysis to monitor spatial and temporal changes in water quality. J Hazard Mater 100:179-195

Bilgin A, Konanç MU (2016) Evaluation of surface water quality and heavy metal pollution of Coruh river Basin (Turkey) by multivariate statistical methods. Environ Earth Sci 75:1029

Bu H, Meng W, Zhang Y, Wan J (2014) Relationships between land use patterns and water quality in the Taizi River basin. China Ecol Indic 41:187-197

Bzdusek PA, Christensen ER, Lee CM, Pakdeesusuk U, Freedman DL (2006) PCB congeners and dechlorination in sediments of Lake Hartwell, South Carolina, determined from cores collected in 1987 and 1998. Environ Sci Technol 40:109-119. https://doi. org/10.1021/es050194o

Carrer S, Leardi R (2006) Characterizing the pollution produced by an industrial area-chemometric methods applied to the Lagoon of Venice. Sci Total Environ 370:99-116. https://doi.org/10.1016/j. scitotenv.2006.06.002

Chen P, Li L, Zhang H (2015) Spatio-temporal variations and source apportionment of water pollution in Danjiangkou Reservoir Basin. Cent China Water 7:2591-2611

Di-hu Y (2005) Dynamic pollution receiving capacity in HuainanBengbu section of the Huaihe River [J]. Water Resour Prot 4:014

Ding J, Jiang Y, Fu L, Liu Q, Peng Q, Kang M (2015) Impacts of land use on surface water quality in a subtropical River Basin: a case study of the Dongjiang river Basin. Southeast China Water $7: 4427-4445$

Hajigholizadeh M (2016) Water quality modelling using multivariate statistical analysis and remote sensing in South Florida

Helena B, Pardo R, Vega M, Barrado E, Fernandez JM, Fernandez L (2000) Temporal evolution of groundwater composition in an alluvial aquifer (Pisuerga River, Spain) by principal component analysis. Water Rese 34:807-816

Henry RC, Christensen ER (2010) Selecting an appropriate multivariate source apportionment model result. Environ Sci Technol 44:2474-2481. https://doi.org/10.1021/es9018095

Ho K, Hui K (2001) Chemical contamination of the East river (Dongiiang) and its implication on sustainable development in the Pearl River Delta. Environ Int 26:303-308

Hoinaski L, Franco D, Stuetz R, Sivret E, de Melo Lisboa H (2013) Investigation of PM10 sources in Santa Catarina, Brazil through graphical interpretation analysis combined with receptor modelling. Environ Technol 34:2453-2463

HOPKE PK (2010) The application of receptor modeling to air quality data pollution atmosphérique:91-109

Hu W, Wang G, Lv Y (2009) Water quality variation and reasons analysis on the mainstream of Huai river in recent years. Environ Prot Sci 1:109-112

Huang J, Ho M, Du P (2011) Assessment of temporal and spatial variation of coastal water quality and source identification along Macau peninsula. Stoch Environ Res Risk Assess 25:353-361
Huang J, Zhan J, Yan H, Wu F, Deng X (2013) Evaluation of the impacts of land use on water quality: a case study in the Chaohu lake basin The Scientific World Journal 2013

Huang WJ, Chen WY, Chuang YH, Lin YH, Chen HW (2014) Biological toxicity of groundwater in a seashore area: causal analysis and its spatial pollutant pattern. Chemosphere 100:8-15

Huang Z, Han L, Zeng L, Xiao W, Tian Y (2016) Effects of land use patterns on stream water quality: a case study of a small-scale watershed in the Three Gorges Reservoir Area China. Environ Sci Pollut Res 23:3943-3955

Khound NJ, Bhattacharyya KG (2017) Multivariate statistical evaluation of heavy metals in the surface water sources of Jia Bharali river basin North Brahmaputra plain, India. Appl Water Sci 7:2577-2586

King RS, Baker ME, Whigham DF, Weller DE, Jordan TE, Kazyak PF, Hurd MK (2005) Spatial considerations for linking watershed land cover to ecological indicators in streams. Ecol Appl 15:137-153

Kuang C et al (2016) Assessment of heavy metal contamination in water body and riverbed sediments of the Yanghe river in the Bohai sea China. Environ Earth Sci 75:1105

Li B, Pu P-M (2003) Study on the evolution tendency of water quality in Huai River basin and Hongze Lake. Resour Environ Yangtze Basin 12:67-73

Li B, Pu P-M, Han A-M (2003) Factor analysis of water quality in Hongze lake China. Environ Sci 23:69-73

Li Y, Xu L, Li S (2009) Water quality analysis of the Songhua River Basin using multivariate techniques. J Water Resour Prot 1:110

Li S, Xia X, Tan X, Zhang Q (2013) Effects of catchment and riparian landscape setting on water chemistry and seasonal evolution of water quality in the upper Han river basin China. PLoS ONE 8:e53163

Li H, Hopke PK, Liu X, Du X, Li F (2015) Application of positive matrix factorization to source apportionment of surface water quality of the Daliao river basin, northeast China. Environ Monit Assess 187:1-12

Liu CW, Lin KH, Kuo YM (2003) Application of factor analysis in the assessment of groundwater quality in a blackfoot disease area in Taiwan. Sci Total Environ 313:77-89

Liu J, Zhang X, Xia J, Wu S, She D, Zou L (2016) Characterizing and explaining spatio-temporal variation of water quality in a highly disturbed river by multi-statistical techniques. SpringerPlus 5:1171

Liu J, Zhang X, Wu B, Pan G, Xu J, Wu S (2017) Spatial scale and seasonal dependence of land use impacts on riverine water quality in the Huai River basin China. Environ Sci Pollut Res 24:20995-21010

Mohammed MO, Song WW, Ma YL, Liu LY, Ma WL, Li WL, Li YF, Wang FY, Qi MY, Lv N, Wang DZ (2016) Distribution patterns, infiltration and health risk assessment of PM2. 5-bound PAHs in indoor and outdoor air in cold zone. Chemosphere 155:70-85

Norris G, Duvall R, Brown S, Bai S (2014) Epa positive matrix factorization (pmf) 5.0 fundamentals and user guide prepared for the us environmental protection agency office of research and development, washington, dc. Washington, DC

Paatero P (1997) Least squares formulation of robust non-negative factor analysis. Chemom Intell Lab Syst 37:23-35

Pacheco FAL (1998) Application of correspondence analysis in the assessment of groundwater chemistry. Math Geol 30:129-161

Parinet B, Lhote A, Legube B (2004) Principal component analysis: an appropriate tool for water quality evaluation and managementapplication to a tropical lake system. Ecol Model 178:295-311

Park J-H et al (2011) Implications of rainfall variability for seasonality and climate-induced risks concerning surface water quality in East Asia. J Hydrol 400:323-332 
Pratt B, Chang H (2012) Effects of land cover, topography, and built structure on seasonal water quality at multiple spatial scales. J Hazard Mater 209:48-58. https://doi.org/10.1016/j.jhazm at.2011.12.068

Simeonov V et al (2003) Assessment of the surface water quality in Northern Greece. Water Res 37:4119-4124

Singh KP, Malik A, Mohan D, Sinha S (2004) Multivariate statistical techniques for the evaluation of spatial and temporal variations in water quality of Gomti river (India) - a case study. Water Res 38:3980-3992

Soonthornnonda P, Christensen ER (2008) Source apportionment of pollutants and flows of combined sewer wastewater. Water Res 42:1989-1998

Sun R, Chen L, Chen W, Ji Y (2013) Effect of land-use patterns on total nitrogen concentration in the upstream regions of the Haihe river Basin China. Environ Manag 51:45-58

Sundaray SK, Panda UC, Nayak BB, Bhatta D (2006) Multivariate statistical techniques for the evaluation of spatial and temporal variations in water quality of the Mahanadi river-estuarine system (India)-a case study. Environ Geochem Health 28:317-330

Tong ST, Chen W (2002) Modeling the relationship between land use and surface water quality. J Environ Manag 66:377-393

Unwin M, Snelder T, Booker D, Ballantine D, Lessard J (2010) Predicting water quality in New Zealand rivers from catchment-scale physical, hydrological and land cover descriptors using random forest models Ministry for the environment, NIWA Client Report: CHC2010-0. National Institute of Water and Atmospheric Research, Christchurch

Wang J, Liu G, Liu H, Lam PK (2017) Multivariate statistical evaluation of dissolved trace elements and a water quality assessment in the middle reaches of Huaihe River Anhui, China. Sci Total Environ 583:421-431

Whitehead P, Wilby R, Battarbee R, Kernan M, Wade AJ (2009) A review of the potential impacts of climate change on surface water quality. Hydrol Sci J 54:101-123

World Bank (1997) China - Huai river basin pollution control project. World Bank, Washington, DC. http://documents.worldbank.org/ curated/en/1997/09/694467/china-huai-river-basin-pollution-contr ol-project
Xia J, Wang L, Yu J, Zhan C, Zhang Y, Qiao Y, Wang Y (2018) Impact of environmental factors on water quality at multiple spatial scales and its spatial variation in Huai river basin. Sci China Earth Sci 61:82-92

Xiao M, Wang S, Bao F, Cui F, Kang J (2011) Concentrations of heavy metals in economic aquatic animals in Huai river segment of Bengbu sampling points East China. Res Environ Sci 24:942-948

Xiao M, Bao F, Wang S, Cui F (2016) Water quality assessment of the Huaihe River segment of Bengbu (China) using multivariate statistical techniques. Water Resour 43:166-176

Ye Y, He X, Chen W, Yao J, Yu S, Jia L (2014) Seasonal water quality upstream of Dahuofang reservoir, China-the effects of land use type at various spatial scales. CLEAN-Soil Air Water 42:1423-1432

Yin Z-Y et al (2005) An analysis of the relationship between spatial patterns of water quality and urban development in Shanghai China. Comput Environ Urban Syst 29:197-221

Yu S, Xu Z, Wu W, Zuo D (2016) Effect of land use types on stream water quality under seasonal variation and topographic characteristics in the Wei river basin China. Ecol Indic 60:202-212

Zhang Y, Xia J, Liang T, Shao Q (2010) Impact of water projects on river flow regimes and water quality in Huai River Basin. Water Resour Manag 24:889-908

Zhao J, Lin L, Yang K, Liu Q, Qian G (2015) Influences of land use on water quality in a reticular river network area: a case study in Shanghai China. Landsc Urban Plan 137:20-29

Zhong M (2006) Evaluation of the implementation of water pollution prevention and control plans in China: the case of Huai river basin Ms for water scarcity - analytical and advisory assistance program. World Bank, Washington, DC

Zhou F, Huang GH, Guo H, Zhang W, Hao Z (2007) Spatio-temporal patterns and source apportionment of coastal water pollution in eastern Hong Kong. Water Res 41:3429-3439

Publisher's Note Springer Nature remains neutral with regard to jurisdictional claims in published maps and institutional affiliations. 